\title{
Tıbbi ve aromatik bitkilerin dünyadaki ve Türkiye'deki ekonomik durumu
}

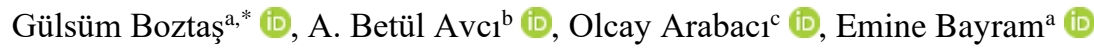

\begin{abstract}
Özet: Bu çalışmada dünya ve Türkiye ticaretinde önemli bir yere sahip olan bazı tıbbi ve aromatik bitkilerin son beş yılına ait ithalat ve ihracat verileri sunulmuștur. Çalışma bulguları International Trade Center (ITC) ve Türkiye İstatistik Kurumu (TÜİK)'ndan elde edilen istatiksel veriler kullanılarak hazırlanmıştır. Tıbbi ve aromatik bitkiler ve bu bitkilerden imal edilen ürünlerin ticaretine ilişkin verilerin 2001 yılı itibariyle Comtrade (International Trade Center-ITC) veri tabanında yer aldığı görülmüştür. Dünya tıbbi ve aromatik bitkiler ve bunlardan elde edilen ürünlerin ihracat değeri 2001 yılında 48.7 milyar dolar iken, 2019 yılında bu değer 207.5 milyar dolara yükselmiștir. İthalat değerinde de aynı artış trendi yakalanmış olup 2001 yilında 48.9 milyar dolar olan değer 2019 y1lında yaklaşık olarak dört kat artarak 205.9 milyar dolar olarak gerçekleşmişstir. Dünyada görülen artıș eğilimi Türkiye dıș ticaretinde de gözlenmiștir. Türkiye'de tıbbi ve aromatik bitkiler ve ürünlerinin ihracat değeri 2001 yllında 143.6 milyon dolar iken, 2019 yılında 1.02 milyar dolara, ithalat değeri ise 2001 yllında 282.7 milyon dolar iken, 2019 yllında 1.36 milyar dolara yükselmiştir. Ülkemizde tıbbi ve aromatik bitkiler ve ürünlerinin ihraç değerleri genel olarak değerlendirildiğinde y1llar itibariyle en önemli artış uçucu yağlar ve rezinoitler, parfümeri, kozmetik vd. ürün grubunda gerçekleşmiştir. Bu ürün grubuna ilişkin ihraç değerleri 2001-2019 yılları arasında 83.6 milyon dolardan 829.4 milyon dolara ulaşmıştır.

Anahtar kelimeler: İhracat, ithalat, uçucu yağ, rezinoit, baharat
\end{abstract}

\section{Economic status of medicinal and aromatic plants in Turkey and in the world}

Abstract: In this study, it was presented that the last five years export and import data of some medicinal and aromatic plants has an important value in Turkey and world trade. The study findings were prepared by using of statistical data obtained from the International Trade Center (ITC) and the Turkish Statistical Institute (TURKSTAT). It was seen that the data on the trade of medicinal and aromatic plants and products manufactured from these plants were included in the Comtrade (International Trade Center-ITC) database as of 2001. While the export value of medicinal and aromatic plants and their products in the world was 48.7 billion dollars in 2001; this value increased to 207.5 billion dollars in 2019 . The same increase trend has been reached in import value as well; the value was 48.9 billion dollars in 2001, increased approximately four times in 2019 and reached 205.9 billion dollars. The upward trend in the world has also been observed in the foreign trade of Turkey. While the export value of medicinal and aromatic plants and products in Turkey was 143.6 million dollars in 2001; it reached 1.02 billion dollars in 2019. While the import value was 282.7 million dollars in 2001; it increased to 1.36 billion dollars in 2019. When the export values of medicinal and aromatic plants and products were evaluated over the years in our country; it was observed that the most important increase was in the group of essential oils and resinoids, perfumery, cosmetics etc. Export values for this product group were increased from 83.6 million dollars to 829.4 million dollars between 2001-2019.

Key words: export, import, essential oil, resinoid, spice

\section{Giriş}

"Tibbi bitkiler" yapısında bulunan zengin biyoaktif madde içeriği ile terapik aktivite gösteren bitkiler olarak tanımlanırken, "aromatik bitkiler" hoş koku ve tada sahip bitkiler olarak isimlendirilmektedir. İşlev ve kullanım alanları bakımından farklılık gösteren bu iki terim son yıllarda birlikte anılmaya başlamıştır. Geçmişten günümüze gerek besin kaynağı gerekse hastalıkların önlenmesi ve tedavi edilmesinde kullanılan bu bitkiler gıda, tıp, kozmetik ve eczacılı gibi gelişmiş endüstrilerin ham madde kaynaklarını olușturmaktadır. Günümüzde sentetik (kimyasal) kaynaklı olarak geliştirilen birçok ilaç bulunmaktadır. Hem insan hem de doğa üzerinde en az tehdit oluşturan tıbbi bitkilerden elde edilen biyoaktif bileşenlerin sayılarının sürekli artış göstermesiyle birlikte sentetik kimyasallara alternatif olarak kullanımı giderek yaygınlaşmaktadır. Ayrıca insanların tüketim alışkanlıkları, beslenme şekilleri ve yaşamlarını sürdürülebilir kılma eğilimlerindeki değişim nedeni ile de doğal kaynaklara yönelimleri, bu bitkilere olan talebin artmasına olanak sağlamıştır.

Dünya Sağlık Örgütünün 2005 yılında yapmış olduğu bir çalışmaya göre dünyada tıbbi amaçla kullanılan 21.000 çeşit bitki türünün olduğu, yaygın olarak kullanımı olan bitkisel drogların sayisinın 4.000-6.000 arasinda değiştiği, ticareti yapılan bitki sayısının ise yaklaşık olarak 3.000 adet olduğu bildirilmiştir (FAO 2005). Yapılan son araştırmalara göre ise bugün Dünyada tıbbi kullanımı kayıtlara geçmiş 28.187 adet tıbbi bitki bulunmakta olup bunun sadece 4.478 adetinin bitkisel kaynaklı ilaç olarak tıbbi kaynaklarda adı geçmektedir (Allkin 2017 atfen Kırıc1 vd. 2020). Günümüzde kullanılan farmasötik ilaçların \%25'i tıbbi bitkilerden üretilmektedir. Yine FAO (G1da ve Tarım Örgütü)'ya göre Dünya genelinde satılan ilaçların \%30’u bitki materyallerinden türetilen bileşikler içermektedir (FAO 2005).
Ziraat Fakültesi, Ege Üniversitesi, İzmir, Türkiye

b Ödemiş Meslek Yüksekokulu, Ege Üniversitesi, İzmir, Türkiye

c Ziraat Fakültesi, Aydın Adnan Menderes Üniversitesi, Türkiye

Corresponding: gulsumboztas@gmail.com

Received: 20.04.2021, Accepted: 21.05.2021
Citation: Boztaş G, Avcı A.B, Arabacı, O, Bayram E (2021). Tıbbi ve aromatik bitkilerin dünyadaki ve Türkiye'deki ekonomik durumu. Theoretical and Applied Forestry 1: 2733. 
Dünyada tıbbi ve aromatik bitki dış alımını yapan ülkeler içerisinde ABD, Çin, İngiltere, Almanya, Fransa, Hindistan ve Hollanda gibi ülkeler aynı zamanda birçok bitkinin de dış satımını yapan ülkeler arasında yer almaktadır (Binici 2002). Türkiye, coğrafi konumu, iklim ve bitki çeşitliliği, tarımsal potansiyeli, geniş yüzölçümü sayesinde tıbbi ve aromatik bitkiler ticaretinde önde gelen ülkelerden biridir (Bayram vd. 2010).

Türkiye'de iç ve dış ticareti yapılan tıbbi ve aromatik bitkiler hakkında yürütülen bir çalışmaya göre bitki türü sayıs1 alt türler de dahil olmak üzere 347 adet olup, bunlardan 139 türün ihracatı yapılmaktadır (Özgüven vd. 2005).

Bu çalışmada, Dünyada ve Türkiye' de üretimi yapılan ve ticari değeri olan bazı tıbbi ve aromatik bitkilere ilişkin son istatistiksel veriler incelenmiş ve değerlendirilmiştir.

\section{Materyal ve metot}

Araştırma, Uluslararası Ticaret Merkezi (International Trade Center, UN Comtrade-ITC) ve Türkiye Istatistik Kurumu (TUİK) veri tabanlarından alınan istatiksel veriler ve konu ile ilgili daha önce yapılmış yayın, kongre bildirileri ve makalelerden elde edilen bulgulardan yararlanılarak hazırlanmıştır.

Finansal olarak pazar değeri her geçen gün artmakta olan tıbbi ve aromatik bitkiler ve ürünlerinin ekonomisine ait istatistiklerin bir araya getirildiği özel bir sınıflandırma bulunmamaktadır. Örneğin aromatik yapıda olan baharat ve çeşni sınıfına giren birçok tıbbi ve aromatik bitki, aynı zamanda parfüm, kozmetik, ilaç, kişisel bakım ürünleri, esans, şekerleme, alkollü içecekler, bitkisel çay vb. alanlarda da geniş kullanım alanına sahiptir. Bu nedenle tıbbi ve aromatik bitkiler ve bu bitkilerden elde edilen ürünlerin kullanımlarında görülen çeşitlilik, istatistiki olarak ticaretine ilişkin sınıflandırılmayı güçleştirmektedir. Ülkemizde tıbbi ve aromatik bitkiler, 29/12/2018 tarihli ve 30640 sayılı Resmî Gazete'de yayımlanan ve 01/01/2019 tarihinden geçerli olmak üzere yürürlüğe konulan İstatistik Pozisyonlarına Bölünmüş Türk Gümrük Tarife Cetvelinde 9'uncu ve 12'nci fasıllarda yer almaktadır. Gümrük Tarife İstatistik Pozisyon (GTIP) numaraları ürünlerin ithalat ve ihracatının doğru bir şekilde yapılması açısından oldukça önemlidir. Türk Gümrük Tarife Cetvelinde bazı ürün gruplarının özel bir GTIP numarasının olmadığı, böyle bir durumda o ürünün en yakın ürün gruba dahil edilerek "diğerleri” adı altında işlem yapıldığı görülmektedir.

Dünyada tıbbi ve aromatik bitkilerin ticari hacmi ve değerine ilişkin verilere ulaşmak için en doğru ve güvenilir kaynağın merkezi Cenevre'de bulunan Uluslararası Ticaret Merkezi (UN Comtrade) veri bankasıdır. Dünya Gümrük Organizasyonu (WCO) tarafından geliştirilen ve bugün yaklaşık olarak 180 ülkede kullanılan sinıflandırma sistemi "Harmonized Commodity Description and Coding System" HS'dir (Başer 1998; Lange 2006). Avrupa Birliğince kabul edilen ve bugün birçok ülke ve ekonomide yaygın olarak kullanılan HS'nin Türkiye'de kabul edilen sistem karşılığı "Customs Cooperation Council Nomenclature" (CCCN)'dir (Bayram vd. 2010).

Uluslararas1 Ticaret Merkezi istatistiklerinde tıbbi ve aromatik bitki grubu ve ürünleri HS2 (09, 13 ve 33) grubu altında toplanmıştır. Çay, kahve, mate (Paraguay çay1) ve baharat grubunun kodu HS2: 09; lak, sakız, reçine vd. bitkisel öz su ve hülasaların kodu HS2: 13; uçucu yağlar ve rezinoitler, parfümeri, kozmetik vd. ürünler ise HS2: 33 kodu ile kaydedilmiştir.

\section{Bulgular ve tartışma}

Tibbi ve aromatik bitkiler ve bu bitkilerden imal edilen ürünlerin ticaretine ilişkin verilerin 2001 yılı itibariyle Comtrade (International Trade Center-ITC) veri tabanında yer aldığı görülmüştür. Tıbbi ve aromatik bitkiler ve bunlardan elde edilen ürünlerin ihracat değeri 2001 yılında 48.7 milyar dolar iken, 2019 y1lında bu değer 207.5 milyar dolara yükselmiştir. Dünya kahve, çay, mate ve baharat grubunun ihracatı 2001 yılında 12.5 milyar dolar iken 2019 yılı itibariyle toplamda 48.7 milyar dolar değere ulaşmıştır (Tablo 1). İhracatta önde gelen ülkeler Brezilya, Çin, Vietnam, Hindistan ve Almanya'dır. Lak, sakız, reçine vd. bitkisel öz su ve hülasaları ürün grubunun (HS2:13) ihracat değerinin 2001-2019 y1lları arasında dört kat artararak 2.1 milyar dolardan 8 milyar dolara yükseldiği görülmektedir. HS2:13 grubunda en fazla ihracat Çin, Hindistan, ABD, Fransa, Almanya ve İspanya ülkeleri tarafindan gerçekleştirilmiştir (Comtrade 2021).

Tablo 1. Dünya tıbbi ve aromatik bitkiler ve ürünlerinin ihracat değerleri

\begin{tabular}{|c|c|c|c|c|c|c|c|}
\hline \multirow{2}{*}{$\begin{array}{c}\text { HS2 } \\
\text { Kodlar1 }\end{array}$} & \multirow{2}{*}{ Ürünler } & \multicolumn{6}{|c|}{ İhracat Değeri (1000 Dolar) } \\
\hline & & 2001 & 2015 & 2016 & 2017 & 2018 & 2019 \\
\hline 09 & $\begin{array}{l}\text { Kahve, çay, Paraguay çayı, } \\
\text { baharat }\end{array}$ & 12.459 .272 & 48.423 .662 & 48.716 .046 & 51.442 .113 & 50.126 .181 & 48.722 .314 \\
\hline 13 & $\begin{array}{l}\text { Lak, sakız, reçine vd. bitkisel } \\
\text { öz su ve hülasalar }\end{array}$ & 2.152 .527 & 7.082 .013 & 7.008 .715 & 7.171 .537 & 8.166 .952 & 8.056 .025 \\
\hline 33 & $\begin{array}{l}\text { Uçucu yağlar ve rezinoitler, } \\
\text { parfümeri, kozmetik vd. }\end{array}$ & 34.104 .976 & 111.263 .893 & 116.826 .571 & 130.125 .207 & 146.011 .649 & 150.697 .605 \\
\hline & Dünya Toplam & 48.716 .775 & 166.769 .568 & 172.551 .332 & 188.738 .857 & 204.304 .782 & 207.475 .944 \\
\hline
\end{tabular}


Tablo 1 incelendiğinde Dünya tıbbi ve aromatik bitkiler ihracatında en fazla artışın, uçucu yağlar ve rezinoitler, parfümeri, kozmetik vd. ürün grubunda (HS2: 33) olduğu, 2001 yılında 34.1 milyar dolar olan ihracat değerinin 2019 yılına gelindiğinde beş kat artarak 150.7 milyar dolara ulaştığı dikkati çekmektedir. HS2:33 grubunda en fazla ihracat değerine sahip ülkelerin, Fransa, ABD, Almanya ve İrlanda olduğu belirlenmiştir (Comtrade 2021).

İthalat değerinde de aynı artış trendi yakalanmış olup 2001 yılında 48.9 milyar dolar olan değer 2019 yılında yaklaşık olarak dört kat artarak 205.9 milyar dolar olarak değer bulmuştur. 2001-2019 yılları arasında kahve, çay, Paraguay çayı, baharat grubunun ithalat değeri 13.4 milyar dolardan 48.6 milyar dolara yükselmiştir. HS2:09 ürün grubunda en fazla dış alım yapan ülkeler ABD, Almanya, Fransa ve İtalya'dır (Comtrade 2021). Lak, sakız, reçine vd. bitkisel öz su ve hülasaları ürün grubunun ithalat değeri 2.4 milyar dolardan 8.0 milyar dolara yükselmiştir (Tablo 2). HS2:13 ürün grubu ithalatında $\mathrm{ABD}$ en büyük paya sahipken, Almanya, Fransa ve Çin onu takip eden başlıca ülkelerdir. Dünya tıbbi ve aromatik bitkiler ve ürünlerinin ihracatında olduğu gibi yıllar içinde en büyük değişim yaratan ürün grubu uçucu yağlar ve rezinoitler, parfümeri, kozmetik vd. olup ithalat değerleri 33 milyar dolar ile 149.2 milyar dolar arasında değişim göstermiştir (Tablo 2). Bu ürün grubunda en fazla diş alım başta Çin, ABD, Almanya olmak üzere İngiltere, Hong Kong ve Fransa tarafından yapılmıştır (Comtrade 2021).

Tablo 2. Dünya tıbbi ve aromatik bitkiler ve ürünlerinin ithalat değerleri

\begin{tabular}{|c|c|c|c|c|c|c|c|}
\hline \multirow{2}{*}{$\begin{array}{l}\text { HS2 } \\
\text { Kodlar1 }\end{array}$} & \multirow{2}{*}{ Ürünler } & \multicolumn{6}{|c|}{ İthalat Değeri (1000 Dolar) } \\
\hline & & 2001 & 2015 & 2016 & 2017 & 2018 & 2019 \\
\hline 09 & $\begin{array}{l}\text { Kahve, çay, Paraguay çayı, } \\
\text { baharat }\end{array}$ & 13.444 .021 & 47.723 .613 & 47.140 .229 & 50.849 .608 & 50.236 .832 & 48.613 .975 \\
\hline 13 & $\begin{array}{l}\text { Lak, sakız, reçine vd. bitkisel } \\
\text { öz su ve hülasalar }\end{array}$ & 2.448 .127 & 6.901 .918 & 6.581 .067 & 7.184 .497 & 7.975 .246 & 8.009 .305 \\
\hline 33 & $\begin{array}{l}\text { Uçucu yağlar ve rezinoitler, } \\
\text { parfümeri, kozmetik vd. }\end{array}$ & 33.040 .770 & 110.771 .779 & 116.152 .674 & 128.292 .491 & 144.545 .822 & 149.263 .820 \\
\hline & Dünya Toplam & 48.932 .918 & 165.397 .310 & 169.873 .970 & 186.326 .596 & 202.757 .900 & 205.887 .100 \\
\hline
\end{tabular}

Kaynaklar: Comtrade, 2021 ve Tüik, 2021 (Dış Ticaret İstatistikleri)

Dünyada görülen artış eğilimi Türkiye dış ticaretinde de gözlenmiştir. Türkiye tıbbi ve aromatik bitkiler ve ürünlerinin ihracat değerine ilişkin veriler Tablo 3'te verilmiştir. Tibbi ve aromatik bitkilerin ihracatı 20012019 yılları arasında \%707 oranında artmış 143.6 milyon dolardan 1.02 milyar dolara ulaşmıştır. İhracatta uçucu yağlar ve rezinoitler, parfümeri, kozmetik vd. ürün grubu 829.4 milyon dolar ile en büyük paya sahipken, Dünya ticaretinde söz sahibi olduğumuz ürünler olan kekik, defne ve haşhaş bitkilerinin yer aldığı ürün grubunun (çay, kahve, Paraguay çayı, baharat) ihracat değeri 168.3 milyon dolar ile ikinci sirada yer almaktadır. HS2:09 ürün grubunda değer olarak ABD, Almanya, Vietnam ve Hollanda en fazla ihracat yaptığımız ülkeler konumundadir (Comtrade 2021).
Türkiye bitkisel drog ihracatı yapan ülkeler arasında önemli bir yere sahiptir. Buna karşın birçok tıbbi ve aromatik bitkinin de ithalatını gerçekleştirmektedir. Türkiye tıbbi ve aromatik bitkiler ve ürünlerinin ithalat değerine ilişkin veriler Tablo 4'de sunulmuştur. HS2:09 kodunda yer alan ürün grubunun 2001 y1lında 26.6 milyon dolar olan ithalat değerinin 2019 yılında yaklaşık olarak 11 kat artarak 282.1 milyon dolara ulaştığ görülmektedir. Aynı artış trendi HS2:13 ve HS2:33 ürün gruplarında belirgin bir fark yarattığ 1 Tablo 4'de izlenmektedir. HS2:09 kodunda en fazla diş alım gerçekleştirilen ülkeler başta Brezilya, Sri Lanka, Hollanda olmak üzere Vietnam ve Suriye; HS2:13 kodunda Fransa, Almanya ve Çin; HS2:33 ürün grubunda ise Almanya, Fransa ve İrlanda'dır (Comtrade 2021).

Tablo 3. Türkiye tıbbi ve aromatik bitkiler ve ürünlerinin ihracat değerleri

\begin{tabular}{|c|c|c|c|c|c|c|c|}
\hline \multirow{2}{*}{$\begin{array}{r}\text { HS2 } \\
\text { Kodu }\end{array}$} & \multirow{2}{*}{ Ürünler } & \multicolumn{6}{|c|}{ İhracat Değeri (1000 Dolar) } \\
\hline & & 2001 & 2015 & 2016 & 2017 & 2018 & 2019 \\
\hline 09 & $\begin{array}{l}\text { Kahve, çay, Paraguay çayı, } \\
\text { baharat }\end{array}$ & 57.908 & 168.481 & 196.162 & 178.338 & 180.685 & 168.349 \\
\hline 13 & $\begin{array}{l}\text { Lak, sakız, reçine vd. bitkisel } \\
\text { öz su ve hülasalar }\end{array}$ & 2.043 & 9.107 & 10.283 & 12.003 & 16.387 & 18.486 \\
\hline 33 & $\begin{array}{l}\text { Uçucu yağlar ve rezinoitler, } \\
\text { parfümeri, kozmetik vd. }\end{array}$ & 83.613 & 695.467 & 696.446 & 762.425 & 782.920 & 829.406 \\
\hline & TÜRKIYYE & 143.564 & 873.055 & 902.891 & 952.766 & 979.992 & 1.016 .241 \\
\hline & Dünya Toplam & 48.716 .775 & 166.769 .568 & 172.551 .332 & 188.738 .857 & 204.304 .782 & 207.475 .944 \\
\hline
\end{tabular}

Kaynaklar: Comtrade, 2021 ve Tüik, 2021 (Dış Ticaret İstatistikleri) 
Tablo 4. Türkiye tıbbi ve aromatik bitkiler ve ürünlerinin ithalat değerleri

\begin{tabular}{|c|c|c|c|c|c|c|c|}
\hline \multirow{2}{*}{$\begin{array}{r}\text { HS2 } \\
\text { Kodu }\end{array}$} & \multirow{2}{*}{ Ürünler } & \multicolumn{6}{|c|}{ İthalat Değeri (1000 Dolar) } \\
\hline & & 2001 & 2015 & 2016 & 2017 & 2018 & 2019 \\
\hline 09 & $\begin{array}{l}\text { Kahve, çay, Paraguay çayı, } \\
\text { baharat }\end{array}$ & 26.560 & 199.780 & 215.998 & 319.580 & 266.302 & 282.124 \\
\hline 13 & $\begin{array}{l}\text { Lak, sakız, reçine vd. bitkisel } \\
\text { öz su ve hülasalar }\end{array}$ & 18.544 & 39.577 & 42.599 & 43.861 & 51.754 & 50.966 \\
\hline \multirow[t]{3}{*}{33} & $\begin{array}{l}\text { Uçucu yağlar ve rezinoitler, } \\
\text { parfümeri, kozmetik vd. }\end{array}$ & 237.606 & 1.101 .905 & 1.113 .790 & 1.200 .318 & 1.141 .906 & 1.024 .344 \\
\hline & TÜRKIYE & 282.710 & 1.341 .262 & 1.372 .387 & 1.563 .759 & 1.459 .962 & 1.357 .434 \\
\hline & Dünya Toplam & 48.932 .918 & 165.397 .310 & 169.873 .970 & 186.326 .596 & 202.757 .900 & 205.887 .100 \\
\hline
\end{tabular}

Kaynaklar: Comtrade, 2021 ve Tüik, 2021 (Dış Ticaret İstatistikleri)

Türkiye sahip olduğu coğrafi konum, zengin bitki çeşitliliği, iklim ve ekolojik yapısı ile geniş yüzölçümü sayesinde tıbbi ve aromatik bitkiler ticaretinde önde gelen ülkeler arasında yer almaktadır. Günümüzde gelişmiş birçok ülkede mevcut kullanımı giderek artan bitkisel ilaç, gida ve katkı maddeleri, kozmetik, parfümeri gibi gelişmiş endüstrilerin hammadde kaynağ olarak kullanılan tıbbi ve aromatik bitkiler ülkemiz florasında yaygın olarak bulunmaktadır (Bayram vd. 2010). Türkiye Dünya genelinde yaklaşık 100 ülkeye tıbbi bitki ihracatı yapmaktadır. İhracatı yapılan türler içinde örneğin; defne, ıhlamur, mahlep, çemen, ardıç ve meyan kökü gibi bitkiler doğadan toplanırken, haşhaş, kimyon, kekik, çay, anason, çörekotu ve kişniş gibi birçok bitkinin de kültürü yapılmaktadır. Yetiştiriciliği yapılan türler içerisinde haşhaş, kekik, defne ve siyah çay en fazla dış satımı gerçekleştirilen bitkilerdir.

Türkiye'nin 2015 ve 2019 yılları arasında baharat, çay ve diğer ürünlerinin ihracat miktar ve değerlerine ilişkin veriler Tablo 5'te sunulmuştur. Tablo incelendiğinde 2019 yılında haşhaşın hem miktar hem de değer olarak en fazla dış satımı yapılan bitki olduğu görülmektedir. Dünyada yasal olarak haşhaş üretimi yapan ülkeler Türkiye, Hindistan, Avustralya, Fransa, İspanya ve
Macaristan olup, bu ülkeler Birleşmiş Milletler Teşkilatı tarafından denetlenmektedir. Birleşmiş Milletler, haşhaş ekimi yapan ülkeler arasında Türkiye ve Hindistan'1 geleneksel haşhaş üreticisi olarak kabul etmektedir (TMO 2019). Haşhaş bitkisinin hem tohumu hem de meyve kabuğundan elde edilen alkaloitlerinin ihracatı gerçekleştirilmektedir (Arslan vd. 2015; Temel vd. 2018). Geçtiğimiz son beş yıl içeresinde haşhaş tohumu ihracat miktarında dalgalanmalar olduğu, değer olarak ise en fazla artışın 2019 yılında (90.5 milyon dolar) gerçekleştiği Tablo 5'te görülmektedir.

Dünya kekik ticaretinin \%80'lik kısmını Türkiye tek başına karşılamaktadır. Ülkemiz sahip olduğu üretim potansiyeli ile Dünya kekik ticaretinde lider ülke konumunda yer almaktadır. Geçtiğimiz son 10 y1l içerisinde ihraç edilen kekiğin yaklaşık \%80'lik kısmının kültür koşullarında üretildiği, kalanın ise doğandan toplandığı bilinmekteydi (Akın 2009'a atfen Bayram vd. 2010). Günümüzde ise bu oran üretim alan ve miktarının artmasına paralel olarak değişmiş, ihraç edilen kekiğin yaklaşık \%90'1 tarla koşullarında üretilirken \%10'u ise doğadan toplanmaktadır (Akın 2020). Yillar itibariyle kekik üretim miktarları Şekil 1'de verilmiştir (Tüik 2021).

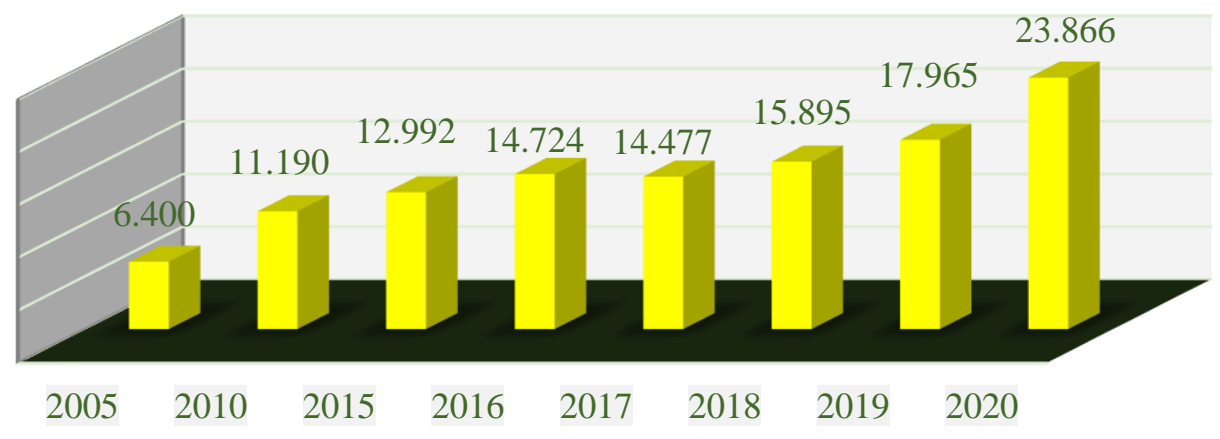

Şekil 1. Yıllar itibariyle kekik üretim miktarları (ton) (Tüik, Bitkisel Üretim İstatistikleri 2021) 
Tablo 5'te görüldüğü gibi 2019 yılında dış satımı gerçekleştilen bitkiler içinde kekik, 16.781 ton miktar ve 53.3 milyon dolar değer ile ikinci sırada yer almaktadır. En önemli ihraç kalemlerimizden bir diğer ürünümüz de defne yaprağıdır. Yüksek kalitede defne yaprağı üreten ülkemiz için Dünya ticaretinde "Gerçek Defne Yaprağ1 Türkiye'den Gelir" ifadesi kullanılmaktadır (Bayram vd. 2010). 2000 yilinda 4.423 ton ve 7.9 milyon dolar (Kırıc1 vd. 2020) olan defne yaprağı ihracatı 2019 yılına gelindiğinde miktar olarak üç kat artarak 13.513 tona, değer bakımından ise yaklaşık olarak beş kat artarak 38.2 milyon dolara ulaşmıştır (Tablo 5). Türkiye'nin 2015 ve 2019 yılları arasında baharat, çay ve diğer ürünlerinin ihracat miktar ve değerleri genel olarak değerlendirildiğinde toplam ihracat miktarının 62.505 tondan 79.258 tona; ihracat değerinin ise 215.6 milyon dolar' dan 269.3 milyon dolara yükseldiği görülmektedir. Önemli bir tıbbi ve aromatik bitki ihracatçısı olan ülkemiz bazı bitki türlerinin de ithalatını yapmaktadır. Türkiye'nin baharat, çay ve diğer ürünlerinin 2015 ve 2019 yılları arasındaki ithalat miktar ve değerleri Tablo 6'da sunulmuştur. 2015 yılında 81.449 ton olan ithalat miktarı 2019 yılına gelindiğinde 137.547 tona ulaşmış, ithalat değeri ise 214.9 milyon dolardan, 300.9 milyon dolara yükselmiştir. Dış alım yapılan bitkiler içerisinde kahve, karabiber, zencefil, zerdeçal, ginseng, küçük hindistan cevizi ve tarçın gibi türlerin ülkemiz koşullarında tarımını yapmak mümkün olmadığı için mutlak ithalatçı konumunda olduğumuz ürünler arasında yer almaktadır. Bu türler arasında en fazla ithalatı gerçekleştirilen ürünler içinde 2019 yılı itibariye 73.563 ton ve 194.7 milyon dolar ile kahve ilk sıradadır. En fazla kahve dış alımı yaptığımız ülkeler arasında Brezilya en büyük paya sahipken, Hollanda, Kolombiya, İtalya ve Almanya onu takip etmektedir (Comtrade 2021).

Tablo 6 incelendiğinde ihracatında söz sahibi olduğumuz ve üretimini yaptığımız ürünlerin aynı zamanda ithal edildiği de görülmektedir. Bu duruma maliyetlerin daha uygun olması, üretimin yeterli olmaması ve ülkemizde baharat işleme teknolojilerinin ileri seviyede olması rol oynamaktadır (Kırıcı vd. 2020). Dış alımı yapılan söz konusu ürünler işlenerek "reeksport" olarak tekrar ihraç edilmektedir. Reeksport olarak ihraç edilen ürünler içinde kahve ve karabiber büyük yer tutmaktadır. Ayrıca en önemli ihraç ürünlerimizden birisi olan dĐefne yaprağında da dış alım yapıldığı Tablo 6'da dikkati çekmektedir. Yukarıda sayılan nedenlere ek olarak arz ve talep dengesi bakımından özellikle Avrupa'da Gürcistan Defnesinin tercih edilmesi nedeniyle ithal edilip reeksport olarak ihracatı yapılmaktadır (Öztürk vd. 2016).

Tablo 5. Türkiye'de 2015 ve 2019 yılları arasında baharat, çay ve diğer ürünlerin ihracatı (Miktar: ton, Değer: 1000\$)

\begin{tabular}{|c|c|c|c|c|c|c|c|c|c|c|}
\hline \multirow{2}{*}{ Bitki Adı } & \multicolumn{2}{|c|}{2015} & \multicolumn{2}{|c|}{2016} & \multicolumn{2}{|c|}{2017} & \multicolumn{2}{|c|}{2018} & \multicolumn{2}{|c|}{2019} \\
\hline & Miktar & Değer & Miktar & Değer & Miktar & Değer & Miktar & Değer & Miktar & Değer \\
\hline Haşhaş (Tohumu) & 12.125 & 37.688 & 20.429 & 56.510 & 3.773 & 10.996 & 26.132 & 76.844 & 25.194 & 90.480 \\
\hline Kekik & 15.153 & 55.703 & 17.048 & 60.380 & 17.709 & 56.931 & 17.402 & 56.227 & 16.781 & 53.250 \\
\hline Defne & 12.724 & 35.831 & 14.073 & 40.701 & 12.709 & 36.059 & 14.589 & 40.196 & 13.513 & 38.235 \\
\hline Siyah çay & 5.442 & 22.717 & 6.075 & 27.800 & 5.107 & 23.725 & 3.500 & 12.338 & 3.898 & 14.025 \\
\hline Kimyon & 3.765 & 11.134 & 8.300 & 22.916 & 4.847 & 15.519 & 7.089 & 21.374 & 3.898 & 13.381 \\
\hline Kahve & 780 & 7.162 & 1.114 & 9.225 & 1.396 & 10.704 & 1.733 & 12.081 & 2.021 & 13.299 \\
\hline Anason & 3.250 & 11.589 & 3.610 & 12.629 & 1.967 & 7.285 & 2.611 & 10.691 & 2.152 & 8.760 \\
\hline Biberler* & 1.731 & 7.311 & 2.163 & 7.887 & 2.415 & 9.097 & 2.468 & 8.896 & 2.600 & 8.687 \\
\hline Adaçayı & 2.070 & 8.065 & 2.071 & 7.651 & 1.908 & 7.057 & 1.961 & 7.182 & 2.317 & 8.681 \\
\hline Sumak & 1.743 & 4.199 & 1.738 & 4.576 & 1.943 & 4.545 & 2.261 & 4.868 & 2.089 & 4.800 \\
\hline Keçiboynuzu & 1.109 & 1.772 & 1.606 & 1.772 & 1.782 & 2.336 & 1.660 & 5.941 & 1.429 & 3.575 \\
\hline Meyan Kökü & 920 & 1.523 & 291 & 790 & 897 & 2.722 & 1.090 & 3.168 & 1.126 & 3.496 \\
\hline Nane & 361 & 1.314 & 374 & 1.360 & 636 & 1.865 & 669 & 2.105 & 647 & 1.526 \\
\hline Karabiber & 178 & 1.871 & 153 & 1.574 & 187 & 1.558 & 197 & 1.508 & 238 & 1.488 \\
\hline Çörekotu & 52 & 244 & 116 & 462 & 462 & 1.361 & 468 & 1.097 & 592 & 1.237 \\
\hline Ihlamur & 62 & 666 & 33 & 462 & 51 & 728 & 135 & 1.812 & 108 & 1101 \\
\hline Yeșil çay & 48 & 896 & 42 & 785 & 77 & 1241 & 65 & 752 & 67 & 1.105 \\
\hline Mahlep & 214 & 4.674 & 141 & 2.485 & 127 & 1.933 & 128 & 1.291 & 117 & 1.096 \\
\hline Çemen & 142 & 217 & 75 & 117 & 43 & 60 & 101 & 134 & 196 & 594 \\
\hline Kişniş & 167 & 307 & 152 & 268 & 137 & 184 & 150 & 200 & 110 & 226 \\
\hline Çöven & 449 & 653 & 302 & 426 & 577 & 683 & 369 & 386 & 123 & 188 \\
\hline Sarımsak (kuru) & 20 & 63 & 399 & 316 & 773 & 543 & 297 & 400 & 42 & 52 \\
\hline Rezene** & - & - & - & - & - & - & - & - & - & - \\
\hline Genel Toplam & 62.505 & 215.599 & 80.305 & 261.092 & 59.523 & 197.132 & 85.075 & 269.491 & 79.258 & 269.282 \\
\hline
\end{tabular}

*Capsicum ve Pimenta cinsi, **Rezeneye ait veriler 2015 yılından itibaren Comtrade ve Tüik istatistiklerinde anasona dahil edilmiştir. Kaynaklar: Comtrade, 2021 ve Tüik, 2021 (Dış Ticaret İstatistikleri) 
Tablo 6. Türkiye'de 2015 ve 2019 yılları arasında baharat, çay ve diğer ürünlerin ithalatı (Miktar: ton, Değer: $1000 \$$ )

\begin{tabular}{|c|c|c|c|c|c|c|c|c|c|c|}
\hline \multirow{2}{*}{ Bitki Adı } & \multicolumn{2}{|c|}{2015} & \multicolumn{2}{|c|}{2016} & \multicolumn{2}{|c|}{2017} & \multicolumn{2}{|c|}{2018} & \multicolumn{2}{|c|}{2019} \\
\hline & Miktar & Değer & Miktar & Değer & Miktar & Değer & Miktar & Değer & Miktar & Değer \\
\hline Kahve & 46.151 & 146.799 & 43.041 & 130.503 & 55.238 & 191.808 & 59.768 & 186.584 & 73.563 & 194.729 \\
\hline Siyah çay & 5.432 & 16.190 & 14.909 & 40.147 & 21.465 & 58.460 & 15.288 & 37.312 & 18.961 & 38.943 \\
\hline Biberler* & 5.346 & 10.698 & 6.599 & 12.710 & 16.054 & 32.676 & 6.519 & 12.009 & 10.797 & 16.187 \\
\hline Karabiber & 3.127 & 5.658 & 4.186 & 7.831 & 6.288 & 15.087 & 3.678 & 839 & 6.249 & 11.362 \\
\hline Keçiboynuzu & 4.912 & 5.039 & 1.306 & 1.748 & 5.641 & 7.655 & 2.462 & 4.167 & 3.528 & 9.480 \\
\hline Sarımsak (kuru) & 2.522 & 8.136 & 2.510 & 8.044 & 415 & 1.357 & 420 & 607 & 5.973 & 6.711 \\
\hline Kekik & 1.348 & 3.875 & 1.658 & 4.750 & 1.517 & 3.963 & 1.788 & 4.749 & 2.165 & 6.166 \\
\hline Kimyon & 1.791 & 4.439 & 2.062 & 5.527 & 2.295 & 6.089 & 1.004 & 3.291 & 2.520 & 5.582 \\
\hline Zencefil & 1.951 & 1.801 & 2.712 & 2.346 & 2.933 & 3.237 & 2.991 & 3.295 & 2.983 & 3.305 \\
\hline Tarçın & 1.219 & 1.265 & 1.781 & 2.083 & 2.281 & 3.396 & 1.154 & 1.901 & 1.896 & 3.177 \\
\hline Anason & 1.041 & 2.594 & 1.889 & 4.258 & 2.273 & 4.763 & 3.613 & 6.589 & 1.817 & 3.122 \\
\hline Adaçayı & 838 & 1.927 & 1.446 & 3.009 & 942 & 1.824 & 744 & 1.621 & 1.073 & 2.646 \\
\hline Çörekotu & 2.898 & 3.017 & 3.466 & 3.657 & 5.501 & 5.558 & 2.429 & 2.512 & 2.648 & 2.532 \\
\hline Kakule & 153 & 570 & 198 & 746 & 233 & 1.056 & 205 & 871 & 240 & 982 \\
\hline Zerdeçal & 507 & 608 & 704 & 762 & 783 & 938 & 979 & 1.096 & 1.029 & 981 \\
\hline Karanfil & 306 & 594 & 176 & 353 & 269 & 726 & 279 & 483 & 323 & 836 \\
\hline Kişniş & 511 & 397 & 1.359 & 847 & 1.397 & 745 & 522 & 276 & 1.543 & 734 \\
\hline Yeşil çay & 238 & 825 & 295 & 942 & 457 & 1.469 & 346 & 1.600 & 146 & 532 \\
\hline Defne & 2.302 & 3.455 & 1.678 & 1872 & 1.330 & 1.795 & 990 & 1.523 & 333 & 473 \\
\hline Çöven & 591 & 521 & 551 & 535 & 884 & 884 & 563 & 323 & 668 & 425 \\
\hline Sumak & 132 & 61 & 593 & 298 & 350 & 192 & 451 & 114 & 721 & 316 \\
\hline Ginseng & 0,865 & 55 & 0,42 & 14 & 2 & 140 & 3 & 22 & 1.4 & 137 \\
\hline Haşhaş (Tohum) & 1 & 3 & - & - & 20 & 55 & 46 & 125 & 30 & 132 \\
\hline K. H. Cevizi & 43 & 19 & 57 & 29 & 45 & 53 & 46 & 58 & 37 & 92 \\
\hline Ihlamur & 105 & 398 & 92 & 379 & 25 & 60 & 25 & 54 & 29 & 65 \\
\hline Çemen & 21 & 37 & 30 & 41 & 0,06 & 0,345 & 0,34 & 1 & 24 & 35 \\
\hline Rezene** & - & - & - & - & - & - & - & - & - & - \\
\hline Mahlep & - & - & 7 & 31 & 2.2 & 7 & 20 & 93 & - & - \\
\hline G. Toplam & 81.449 & 214.882 & 92.714 & 232.038 & 126.288 & 337.391 & 105.592 & 268.686 & 137.547 & 300.908 \\
\hline
\end{tabular}

*Capsicum ve Pimenta cinsi, **Rezeneye ait veriler 2015 yılından itibaren Comtrade ve TÜİK istatistiklerinde anasona dahil edilmiştir. Kaynaklar: Comtrade, 2021 ve Tüik, 2021 (Dış Ticaret İstatistikleri)

\section{Sonuçlar}

Bu çalışmada Dünyada ve Türkiye'de tıbbi ve aromatik bitkiler ve ürünlerin ticaretindeki son gelişmeler irdelenmiştir. Günümüzde tıbbi ve aromatik bitkilerin kullanım alanlarının genişlemesi ve yaygınlaşmasına paralel olarak Dünya ticaretinde de önemli artışlar olduğu görülmektedir. Geçtiğimiz son 20 yıldan bu yana Dünyada tıbbi ve aromatik bitkiler ve ürünlerinin ticaret hacminde görülen değişim son istatistiksel verilere de yansımıştır. Türkiye'de de Dünya ile benzer bir durum söz konusudur. Ülkemiz sahip olduğu coğrafi konum, zengin bitki çeşitliliği, iklim ve ekolojik yapısı ile geniş yüzölçümü sayesinde tıbbi ve aromatik bitkiler ticaretinde önde gelen ülkeler arasında yer almaktadır. Dünyada tıbbi ve aromatik bitkiler ticaretinde görülen artış eğiliminin ülkemiz istatistiklerine de yansıdığı saptanmıştır.

İhraç ettiğimiz tıbbi ve aromatik bitki türlerinden bazılarının tarla koşullarında üretimi yapılırken, büyük bir kısmının da doğadan toplandığı bilinmektedir. Doğadan yapılan toplamalarda bitki toplayıcılarının, hasat dönemi ve yöntemi, sürdürülebilirlik, yoğunluğa göre toplama gibi konularda yeterli bilgi birikimine sahip olmadığı bilinmektedir. Bu nedenle doğadan toplanan bitkilerin belli bir standartta olmamasından kaynaklanan sorunlarla (toplanan bitki türlerinde karışmalar, yabancı otların ürüne karışması, kalitenin istenen düzeyde olmaması vb.) karşılaşılmaktadır. Yine tarımı yapılan/yapılması istenen türlerde ıslah edilmiş çeşit sayısının az olması, tohumluk temininde yaşanan sıkıntılar ve tohumluk üretiminin yeterli miktarda yapılmaması bu bitkilerin üretiminde karşılaşılan en önemli sorunlar olarak karşımıza çıkmaktadır. Bu sorunların çözümü bütünsel bir yaklaşımı gerektirmektedir. Doğadan toplamalar doğal kaynakların ve biyolojik çeşitliliğin korunması açısından sürdürülebilirlik ilkesine uygun olarak yapılmalıdır. Bununla birlikte doğadan toplanan ve getirisi yüksek olan tıbbi/aromatik bitkilerin uygun iklim koşullarında kültüre alınması büyük önem taşımaktadır. Özellikle tüketici profili düşünüldüğünde, organik tarım ve iyi tarım uygulamaları gibi sistemlere bağlı olarak üretimin yapılması ürünlerin pazar değerini arttıracaktır. Yine tıbbi ve aromatik bitki üretiminde dünya ticaret hacmi, arz/talep dengesi gibi faktörlerin dikkate alınarak üretimin planlanması önemli bir konudur. Mevcut sorunların giderilmesi ve tıbbi/aromatik bitki tarımının gelişime katkı sağlayacak sosyal ve teknolojik uygulamaların arttırılması ile ülkemizde istenen kalite ve miktarda standart ürün elde edilerek tıbbi/aromatik bitkiler ve ürünlerin ticaret hacminin artacağ 1 beklenmelidir.

Sonuç olarak, tüketicilerin doğal ürünlere olan yönelimleri ve yaşam kalitelerini iyileştirme ve sürdürmeye yönelik çabaları, önümüzdeki yıllarda da bu bitkilere olan talebi arttıracağını söylemek mümkündür. 


\section{Kaynaklar}

Akın T (2020). Kişisel görüşme. Kütaş Tarım Ürünleri Dış. Tic. San. AŞ. İzmir.

Akın T (2009). Kişisel görüşme. Kütaş Tarım Ürünleri Dış. Tic. San. AȘ. İzmir.

Allkin B (2017). Useful plants-medicines. At least 28,187 plant species are currently recorded as being of medicinal use. In: Willis KJ, editor. Royal Botanic Gardens, London.

Arslan N, Baydar H, Kızıl S, Karik Ü, Şekeroğlu N, Gümüşçü A (2015). Tibbi ve aromatik bitkiler üretiminde değişimler ve yeni arayışlar. TMMOB Ziraat Mühendisliği VIII. Teknik Kongresi,1216 Ocak, Ankara.

Başer H.C (1998). Tıbbi ve aromatik bitkilerin endüstriyel kullanımı. TAB Bülteni 13-14:19-43.

Bayram E, Kırıcı S, Tansił S, Yilmaz, G, Arabacı O, Kızıl Kizil S, Telci İ (2010). Tibbi ve aromatik bitkiler üretiminin arttırılması olanakları. TMMOB Ziraat Mühendisleri Odasi, Ziraat Mühendisligi VII. Teknik Kongresi, 11-15 Ocak, Ankara.

Binici A (2002). Baharat değerlendirme raporu. Orta Anadolu İhracatçı Birlikleri Genel Sekreterliği, 1-37.

Comtrade (2021). International Trade Center. https://www.trademap.org (Erişim tarihi: 18.04.2021)

FAO (2005). Trade in medicinal plants. http://www.fao.org/3/af285e/af285e00.pdf (Erişim Tarihi: 18.04.21).

Kırıcı S, Bayram E, Tansı, S, Arabacı O, Baydar H, Telci İ, İnan M, Kaya D.A, Özel A (2020). Tibbi ve aromatik bitkilerin üretiminde mevcut durum ve gelecek. Türkiye Ziraat Mühendisliği IX.Teknik Kongresi, 13-17 Ocak, Ankara.
Lange D (2006). International trade in medicinal and aromatic plants, medicinal and aromatic plants, 155-170. Nutrition Business Journal (NBJ), 2007. NBJs Supplement Business Report 2006. New Hope.com. nbj.stores.yahoo.net/nbsubure20pr.html.

Özgüven M, Sekin S, Gürbüz B, Şekeroğlu N, Ayanoğlu F, Ekren S (2005). Tütün, tıbbi ve aromatik bitkiler üretimi ve ticareti. Türkiye Ziraat Mühendisliği VI. Teknik Kongresi, 3-7 Ocak, Ankara.

Öztürk M, Temel M, Tınmaz A.B (2016). Türkiye'de defne yaprağ üretimi ve pazarlaması. III. Tibbi ve Aromatik Bitkiler Sempozyumu, 4-6 Ekim, Antalya.

Temel M, Tinmaz A.B, Öztürk M, Gündüz O (2018). Dünyada ve Türkiye'de tıbbi-aromatik bitkilerin üretimi ve ticareti. Tarım ve Doğa Dergisi, 21, 198

Temel M, Tınmaz AB, Öztürk M, Gündüz O (2018). Dünyada ve Türkiye'de Tibbi-Aromatik Bitkilerin Üretimi ve Ticareti. KSÜ Tar Doğa Derg 21(Özel Sayı) : 198-214, DOI : 10.18016/ ksutarimdoga.vi.473036.

TMO (2019). Haşhaş Raporu. https://www.tmo.gov.tr/Upload/Document/hashassektrraporu.pdf

TÜIKK (2021). $\quad$ Bitkisel üretim istatistikleri. https://biruni.tuik.gov.tr/medas $/$ $/ \mathrm{kn}=92 \&$ locale $=\operatorname{tr} \quad$ (Erişim tarihi: 18.04.2021).

TUİK (2021). Diş ticaret istatistikleri. https://biruni.tuik.gov.tr/disticaretapp/menu.zul (Erişim tarihi: 18.04.2021) 